\title{
Brazilian Digital Inclusion Public Policy: achievements and challenges
}

\author{
Cristina Kiomi Mori \\ cristina.mori@planejamento.gov.br \\ Rodrigo Ortiz Assumpção \\ rodrigo.assumpcao@planejamento.gov.br
}

\section{Introduction}

Since 2003, the Brazilian digital inclusion public policy has been oriented towards social participation and the building of a public ICT infrastructure. So far, there have been some achievements and lots of challenges to overcome.

As to present these achievements and challenges, this article begins by describing the context of digital divide in Brazil, with data that is an achievement in itself. Statistics on Internet availability and use in the country has only recently been produced in a more consistent basis, due to the Brazilian Internet Steering Committee (CGI.BR).

Responsible for Internet governance in Brazil, CGI.Br is a "multistakeholder organization composed by members of the government, the enterprise sector, the third sector and the academic community", in which the representatives of the civil society are chosen democratically to participate directly in the deliberations and debate the priorities for the development of the Internet, together with the government representatives (CGI.BR, 2007).

Through the creation of its ICT Studies Centre (CETIC.br), CGI.Br has started to work in a national project for the development of indicators for the Brazilian Internet, which has led to the first national survey on ICT individual access by the Brazilian Geographic and Statistics Institute (IBGE, 2007).

This effort is followed by the National Digital Inclusion Observatory, conducted by the Federal Government Digital Inclusion Committee together with civil society organizations, for mapping and registering all public non-commercial Internet usage places ('telecenters'), among other activities described further.

After bringing the context of digital divide in Brazil, this article will present the Federal Government strategies to face digital divide and describe some of the many ongoing initiatives, with special attention to Computers for Inclusion project (inspired in the Canadian Computers for Schools) and the above mentioned Observatory.

Digital Inclusion public policy challenges will then be raised and commented, from the understanding that government has an extremely important role to play in this context, alongside with civil society.

What this article aims to present, in a whole, is some useful information for comparison with other countries, as well as a tool for discussion and agenda setting for researchers and policy makers, including practitioners from governments and the civil society.

\section{Digital Divide in Brazil: numbers}

In 2005, according to the Brazilian Geographic and Statistics Institute - IBGE, 31.96 million people or 21\% of the population above 10 year-of-age had access to the internet (IBGE, 2007). As expected, Brazilian digital divide follows similar patterns to the indicators for inequality of income distribution and other social indicators.

Percentage of Internet users per family income group - 2005

\begin{tabular}{|l|l|}
\hline $\begin{array}{l}\text { Household income } \\
\text { (minimum wage }{ }^{1} \text { per capita) }\end{array}$ & $\begin{array}{l}\% \text { of internet } \\
\text { users }\end{array}$ \\
\hline No income to $1 / 4$ minimum wage & 3.3 \\
\hline $1 / 4$ to $1 / 2$ min. wage & 5.9 \\
\hline $1 / 2$ to 1 min. wage & 11.6 \\
\hline
\end{tabular}

1 In 2005, the minimum wage was $R \$ 300,00$ (approximately US\$130,00 at that time). 


\begin{tabular}{|l|l|}
\hline 1 to 2 min. wages & 24.8 \\
\hline 2 to 3 min. wages & 42.0 \\
\hline 3 to 5 min. wages & 55.2 \\
\hline More than 5 min. wages & 69.5 \\
\hline
\end{tabular}

Overall, the main place of Internet access was home, followed by work, school and other residences. Among them, 3.2 million accessed the Internet in free access centers - or telecenters.

\section{Percentage of users per place of Internet access -2005}

\begin{tabular}{|l|l|}
\hline Place of internet access & \% of users \\
\hline Home & 50.0 \\
\hline Work & 39.7 \\
\hline School & 25.7 \\
\hline Free public access centre & 10.0 \\
\hline Paid public access centre & 21.9 \\
\hline Other places & 31.1 \\
\hline
\end{tabular}

However, according to another CGI.Br research that considers social classes (CGI.BR, 2006), people of lower (D and E) classes accessed the internet mostly at public centers (paid or free of charge) and school, while the higher social classes accessed it mostly at home and work.

Percentage of people of each social class per place of internet access - 2006

\begin{tabular}{|l|l|l|l|l|l|l|l|}
\hline $\begin{array}{l}\text { Social Class/ place of } \\
\text { internet access (\%) }\end{array}$ & At home & At work & At school & $\begin{array}{l}\text { Other } \\
\text { people's } \\
\text { home }\end{array}$ & $\begin{array}{l}\text { Paid public } \\
\text { access } \\
\text { centre }\end{array}$ & $\begin{array}{l}\text { Free public } \\
\text { access centre }\end{array}$ & $\begin{array}{l}\text { Other } \\
\text { places }\end{array}$ \\
\hline A & 78.04 & 37.16 & 6.85 & 12.53 & 8.06 & 0.07 & 1.05 \\
\hline B & 62.04 & 27.84 & 11.44 & 13.59 & 19.33 & 2.00 & 1.17 \\
\hline C & 27.69 & 24.10 & 17.56 & 18.65 & 35.54 & 4.13 & 2.06 \\
\hline DE & 9.82 & 11.89 & 22.76 & 15.87 & 48.08 & 6.44 & 2.35 \\
\hline
\end{tabular}

Households with personal computers in 2005 were $18.5 \%$. That figure is expected to change in PNAD 2006 by the fact that 7.8 million desktop computers were sold in 2006 in Brazil, an increase of $42 \%$ compared to 2005, according to the ABINEE (2007).

Regarding telecommunication infrastructure, according to IBGE 39.7\% of households did not have access to either landline voice dial-up nor mobile cell phone in 2005 (IBGE, 2006), and only 13.7\% of households had access to the Internet. It is important to notice that the number of municipalities with access to broadband data telecommunication through cable and ADSL has risen from 251 of the country's 5,565 municipalities in 2003 to 1,923 in 2006 (COMPUTERWORLD, 2007). The telecom sector claims that these municipalities represent $72.4 \%$ of the country's population, but do not mention that service coverage within municipalities is concentrated in the richest neighborhoods and city centers.

Despite the fall of desktop computer prices to as low as R $\$ 1,200.00$, average monthly income for more than $50 \%$ of the households was less than R\$ $1,050.00$ in 2005 (IBGE, 2006), which still prevents most Brazilians from having access to computer with Internet at home.

Despite the importance of schools, especially for the access of lower social classes, only $16.7 \%$ had access to the Internet in 2005 (PNUD, 2006) in a total universe of 195,041 public and private elementary and medium level schools. 
These numbers illustrates one important digital divide issue: access to infrastructure. Quality indicators, impact studies and other fundamental aspects concerning the digital divide, relating abilities and use of ICT for development in its multiple dimensions, remain as challenges.

\section{Government Strategies}

Federal Government guidelines for Electronic Government cover Digital Inclusion (BRAZIL, 2004). It is registered there that a digital inclusion public policy must build an infrastructure aimed towards public and community use. The document claims that Federal Government must be responsible for "inductive, normative and budgetary actions". Also that digital inclusion projects must prioritize the expenditure with human resources, and capacity building rather than equipments, connectivity and software licenses". It also states that the "execution of digital inclusion policy must be shared with other governmental levels, private sector and civil society”.

To date, several digital inclusion initiatives under the responsibility of different governmental institutions have been implemented by the Brazilian Federal Government. These initiatives can be grouped in three strategies: a) incentives for personal acquisition of equipments; b) equipping public schools with ICT and access; c) implementation of public/community access centers for universal use.

The first strategy is the focus of the Computers for All program, in which national computer manufacturers register minimum configuration desktop and notebook models with free/open-source software installed. For these models, some taxes are diminished or entirely cut, and vendors can offer special financing rates that make it possible for the final consumer to pay less than $\mathrm{R} \$ 50.00$ a month for a domestic use computer, totalizing $\mathrm{R} \$ 1,200.00$ or less. This program has stimulated price decrease for all models, and together with low dollar-real exchange rates and rising incomes for the $\mathrm{C}$ class, allowed for the above mentioned market rise in desktop and notebook selling, as well as for 2.2 million Brazilians acquiring their first personal computer in 2006 (WNEWS, 2007).

The second strategy, equipping of public schools with ICT and access, is the aim of ProInfo - National Program for Informatics in Education, coordinated by the Ministry of Education since 1997, in co-responsibility with States and municipalities.

The third strategy is the implementation of public Internet access centers for universal use, or telecenters. This strategy concentrates the largest number of decentralized initiatives, such as Casa Brasil, Culture Points, Rural and Fishermen Telecenters and others that can be seen in www.inclusaodigital.gov.br. Successful local government initiatives and international experiences served as examples and inspiration for the dissemination of telecenters throughout the country, not only by the Federal Government but also by local governments and civil society organizations.

In order to provide digital inclusion in households, public schools and community access centers, a public policy must integrate resources such as connectivity, equipments and capacity building, as well as construct and maintain evaluation tools and indicators.

\section{Evaluation tools: National Digital Inclusion Observatory}

An important evaluation tool under construction is the National Digital Inclusion Observatory - ONID, which has started to map and register all public non-commercial Internet usage resources (telecenters). Proposed by the Federal Government Digital Inclusion Committee, in alliance with civil society organizations, the Observatory keeps records on telecenters that are constantly updated and available over the web, so that citizens can follow the implementation and characteristics of the facilities, promote the use of telecenters as well as contribute for their improvement. For the government, the Observatory will allow for organized information on the national coverage of telecenter units, helping public policy building and its improvement, in dialogue with civil society, as well as being a decision making tool concerning the investment and maintenance of telecenter infrastructure.

One of the first achievements of the Observatory was the construction of the digital inclusion federal programs portal, mentioned above (www.inclusaodigital.gov.br). The portal aggregates, in one URL, information about 14 Federal Government digital inclusion ongoing initiatives, including news, events, links for each program and a repository of references in continuous growth for practitioners and academic researchers.

The Observatory has also estimated, in partnership with IPSO - Social and Technology Projects and Research Institute, that the number of operating telecenters in Brazil is from 4,000 to 5,000 in the begining of 2007. Next steps are filling up and checking information about all these units, and making them available in the web.

\section{Computers for Inclusion: equipment refurbishing for schools, telecenters and public libraries}

Another achievement that can be mentioned in Brazilian digital inclusion public policy is the Computer for Inclusion project. It consists of a national network for reconditioning ICT equipment that is no longer useful for companies and government. The project is inspired in the Canadian Computers for Schools program, which began in 1993. 
In Brazil, there are three Computer Refurbishing Centers - CRCs to date. Equipment discarded from private and state owned companies, as well as from government, are directed to these centers, and pass through a semi-industrial process that delivers standard-level computers with free-open-source software installed for use in schools, telecenters and public libraries.

One of the differences between the Canadian program and Computers for Inclusion is that the Brazilian initiative tries to build capacity and promote professional education for youngsters of low-income families living in major city suburbs. To allow for this, CRCs are implemented in poor neighborhoods in partnership with local social nongovernmental organizations that are experts in community development and youth.

Another difference is that the project delivers computers for schools but also for libraries and telecenters. These places are important for bridging digital divide and allow for population capacity building, playing an important role for compensating the lack of formal education of the adult population in Brazil.

The Ministries of Planning, Education and Labor form the National Coordination of the Computers for Inclusion project, together with representatives from the CRCs and other nation-wide partner institutions. The main responsibility of this committee is to evaluate and decide which projects submitted by organizations such as schools, libraries, community associations and other end-user digital inclusion promoters will receive the equipments refurbished in the CRCs.

Until $31^{\text {st }}$ March 2007, Computers for Inclusion had received more than 3,000 used computers, refurbished 551 and donated 283 for 25 digital inclusion projects throughout the country. At that moment, 234 youngsters were working in the CRCs and three new centers were planned to have started implementation by the end of the year.

\section{Challenges}

Despite a noticeable evolution in digital inclusion public policy, many challenges are facing the Brazilian Federal Government and also other actors who aim to improve these initiatives. They can be summed in the guaranteeing of:

- Broadband access to the Internet.

- Funding for the maintenance of existing infrastructure (schools, telecenters).

- Local content production.

- Qualified digital inclusion agents in the initiatives with adequate labor conditions.

- Participative steering mechanisms for programs and digital inclusion initiatives.

- Universal access to facilities in the local level.

- Co-responsibility among Federal, State and municipal government levels.

- Development of local government budgetary and administrative capacity.

\section{a) Broadband access to the Internet}

Access to the Internet shall be treated as a public policy similar to water and energy supply. This means that universalization of broadband service at a feasible fee must be the aim of governments and citizens. Telecom and communications legislation must include responsibilities for government and the private sector to provide broadband as a public service, so as to cover the whole country, and not only urban rich areas. Brazilian Federal Government has started a national broadband plan to provide all schools and municipalities with the service by 2010, and this will demand efforts from many sides.

\section{b) Funding for the maintenance of existing infrastructure}

As important as the goal of expanding the number of facilities available for digital inclusion initiatives, maintaining the existing infrastructure of access remains a challenge. Local communities have significant difficulties in allocating the necessary resources to maintain connectivity, equipments and network, as well as the upkeep of human resources. The full appropriation of ICT by communities is not an immediate result of allocated infrastructure, nor can it ignore that technology keeps changing. Governmental budget allocation is part of the solution, more effective when joined by local governments capable of dialoguing with the communities.

\section{c) Local content production}

ICT cannot be used only for accessing information that is produced elsewhere. One of the challenges of digital inclusion initiatives is to promote local content production and its dissemination. Effective technology appropriation demands methodologies, approaches and strategies that do not consist in the mere reproduction of commands, 
discourses and contents. ICT are to be used as tools, means and languages for the affirmation of cultural identity and diversity. Local content production contributes to development in its multiple dimensions by expressing the points of view and realities of those who live them.

\section{d) Qualified digital inclusion agents in the initiatives in adequate labor conditions}

Enabling local people to act as digital inclusion agents - educators, monitors, telecentrists, activities tutors and so on - in a professional and qualified manner, is still not recognized by numerous public policy makers as the most fundamental issue concerning ICT for development and people. Maintenance of these local agents in adequate labor conditions is an important challenge. If not, qualified agents tend to either move from that place to a (better) paid job, or become over-demanded, affecting the quality of their activities and, in some cases, their relationship with the community. Unfortunately there is significant evidence that voluntary efforts while important and significant do not provide sufficient long-term stability to most initiatives.

\section{e) Participative steering mechanisms for programs and units of digital inclusion}

While there has been a movement towards the establishment of local steering committees in telecenters implemented by most Federal Government initiatives, the programs themselves still lack consolidated mechanisms of participation for civil society, as does the national digital inclusion public policy. Also, many schools have trouble in implementing participative mechanisms at the local level, keeping even their own students and teachers away from ICT infrastructure already available.

\section{f) Universal access to facilities in the local level}

Mostly schools, but also telecenters and other digital inclusion initiatives still have restrictions concerning the use of their facilities by all citizens. Universal access is a necessary guideline and daily effort, in order to promote social inclusion and a more efficient use of public resources. One ally in overcoming these restrictions has been local steering committees structured to represent as many social groups as existent around the unit. These committees do not fear to debate openly the conflict of interests concerning the use of the unit and usually are instrumental in negotiating solutions that keep the public interest foremost. Concerning this challenge it is important to point out that digital inclusion agents must be qualified to attend the diversity of people use the unit, guaranteeing their role as a public service facility.

\section{g) Co-responsibility among Federal, State's and municipal governmental levels}

Every year, more and more government agents, in different levels, feel they have a role to play in digital inclusion. This should be oriented to considering digital inclusion as a public policy, in which each actor has a defined responsibility. There are numerous challenges that could be better embraced if institutional mechanisms were built; this is only possible through the involvement of Federal, State and municipal governments.

\section{h) Budget and capacity building at municipal level}

Brazil has 5,565 municipalities, nearly $80 \%$ sustained by Federal budget transfers, and many with low administrative capacity for using these resources effectively in accordance to legislation and public interest, as well as little capacity to raise local funds for public policies. Initiatives that help these municipalities to assume their roles and responsibilities as public policy implementers must be reinforced and disseminated. As a Federal Republic, Brazilian society expects that National, State and Municipal governments are capable of acting in a coordinated manner, especially in regard to social inclusion policies, such as digital inclusion initiatives.

\section{Conclusion}

From the perspective of agents working within the Federal Government, these are relevant observations about digital inclusion in Brazil today. On one hand, the advances in collecting data and the implementation of some strategies on bridging digital divide are very positive, especially in regard to the increase of home use of computers. On the other hand, broadband access to the Internet as a nation-wide public service, implementation and maintenance of digital inclusion initiatives in schools and public access centers, and qualification of human resources in the use of ICT for development in its multiple dimensions, still remain as challenges that Government in all levels and civil society are facing and are yet to resolve. 


\section{References}

ABINEE - Associação Brasileira da Indústria Elétrica e Eletrônica (Brazilian Electric and Electronic Industry Association). (2006). Sondagem Setorial Janeiro-Agosto/2006. Retrieved in October 03, $2006 \mathrm{em}$ http://www.abinee.org.br/abinee/decon/decon16.htm

BRAZIL. (May 2004). Oficinas de Planejamento Estratégico - Relatório Consolidado - Comitês Técnicos. Comitê Executivo do Governo Eletrônico. Retrieved in December 17, 2006 from http://www.governoeletronico.gov.br/governoeletronico/publicacao/down_anexo.wsp?tmp.arquivo=E15_243di retrizes_governoeletronicol.pdf

CGI.Br - Comitê Gestor da Internet Brasil (Brazilian Internet Steering Committee) website. (2007). Retrieved in April 30, 2007 from http://cgi.br

CGI.BR. (2006). $2^{a}$ Pesquisa Sobre Uso da Tecnologia da Informação e da Comunicação no Brasil - TIC Domicílios e Usuários 2006. Retrieved in April 30, 2007 from http://www.cetic.br/usuarios/tic/2006/rel-int-04.htm

COMPUTERWORLD. (January 31, 2007) Número de municipios com banda larga salta 660\% em 3 anos. Retrieved in April 30, 2007 from http://computerworld.uol.com.br/comunicacoes/2007/01/31/idgnoticia.2007-0131.7117313758/IDGNoticia_view

IBGE - Instituto Brasileiro de Geografia e Estatística (Brazilian Geographics and Statistics Institute). (2007). Pesquisa Nacional por Amostra de Domicílios 2005 - Suplemento Especial Acesso à Internet e Telefone Móvel Celular para Uso Pessoal. Retrieved in April 30, 2007 from http://www.ibge.gov.br/home/estatistica/populacao/acessoainternet/default.shtm

IBGE. (2006). Pesquisa Nacional por Amostra de Domicílios 2005. Retrieved in October 10, 2006 from http://www.ibge.gov.br/home/estatistica/populacao/trabalhoerendimento/pnad2005/default.shtm

PNUD. (2006) Implementação do Sistema Integrado de Informações Educacionais (SIEd). Retrieved in October 10, 2006 from http://www.pnud.org.br/curiosidades/index.php?id04=32\&are=ecu

WNEWS. (February 7, 2007). 2,2 milhões de pessoas compraram seu primeiro computador em 2006. Reproduced in Computador para Todos website. Retrieved in April 30, 2007 from

http://www.computadorparatodos.gov.br/noticias/20070208_01 